J. Perinat. Med $16(1988) 133$

\title{
Intrauterine treatment of idiopathic hydrops fetalis
}

\author{
Hiroshi Shimokawa, Kenji Hara, Hirotaka Maeda, Shingo Miyamoto, Takashi \\ Koyanagi, and Hitoo Nakano
}

Department of Gynecology and Obstetrics, Faculty of Medicine, Kyushu University, Fukuoka, Japan

\section{Introduction}

Non-immune hydrops fetalis (NIHF), caused by disorders other than feto-maternal blood group incompatibility, is the predominant form of hydrops fetalis in developed countries [1]. Though hydrops fetalis can be readily diagnosed antenatally using ultrasound, NIHF is still associated with an extremely high perinatal mortality [8]. Although many fetopathies associated with NIHF have been reported, the etiology and the underlying disorders cannot be determined in approximately 30 percent [14]. In these cases of idiopathic hydrops fetalis (IHF), a characteristic and common finding is hypoproteinemia [11]. The decreased serum protein concentration may play an important role in establishing the clinical picture of hydrops fetalis.

Based on the hypothesis that decreased plasma colloid osmotic pressure due to hypoproteinemia may play a role in the onset and/or progress of IHF, we injected albumin into the fetal abdominal cavity and thus attempted to save the lives of fetuses with IHF.

\section{Materials and methods}

Thirty-three infants with NIHF, diagnosed antenatally, were delivered in the Maternity Care Unit of Kyushu University Hospital from January 1983 to December 1986. There were eleven with IHF (table I). Seven of these eleven were treated in utero. The other four were excluded from the present study. In one case because delivery and neonatal treatment were decided upon because the gestational age (36 weeks) was thought to be

\section{Curriculum vitae}

HIROSHI SHIMOKAWA, M.D., was born in 1948 . He graduated from Kyushu University Medical School in 1975. Since February 1986 he has been an assistant professor in the Department of Gynecology and Obstetrics, Faculty of Medicine, Kyushu University. His main fields of interest include fetotherapy

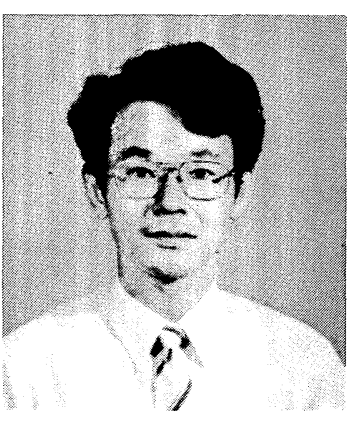
and pregnancy induced hypertension.

sufficiently advanced. In three others, the parents refused intrauterine treatment. All four died soon after birth despite active resuscitation and respiratory care in the NICU.

The protocol for the intrauterine treatment of NIHF consisted of the following: attempts to evaluate the etiology and the underlying disorder; the intrauterine treatment; and the evaluation of therapeutic effects in utero. Intrauterine treatment was performed after obtaining informed consent from the families.

To assess the etiology and the underlying disorders, the following tests were done on the mother: complete blood count, blood group, blood-group antibody, $\mathrm{Hb} \mathrm{F}$ concentration, TORCH screening tests and oral glucose tolerance test. In the fetus, detailed ultrasound examination of the fetal anatomy, fetal echocardiography, optical density difference at $450 \mathrm{~nm}$ in amniotic fluid, and karyotype 
Table I. Underlying disorders in 33 fetuses with NIHF

\begin{tabular}{lc}
\hline Pathologic findings & N \\
\hline Endocardial fibroelastosis & 1 \\
Hypoplastic right ventricle & 1 \\
Ebstein's anomaly & 1 \\
Double outlet of right ventricle & 1 \\
Complete atrioventricular block & 2 \\
Decreased fractional shortening of both & \\
$\quad$ ventricles of unknown origin & 1 \\
Twin - twin transfusion & 2 \\
Lymphangioma & 1 \\
Chyloascites & 1 \\
Chylothorax & 3 \\
Cystic hygroma of neck & 1 \\
Meconium peritonitis & 1 \\
Cystic adenomatoid malformation of the lung & 2 \\
Diaphragmatic hernia & 1 \\
Sacral teratoma & 1 \\
Trisomy 21 & 2 \\
Idiopathic & 11 \\
\hline Total & 33 \\
\hline
\end{tabular}

All infants were delivered in the Maternity Care Unit of Kyushu University Hospital from January 1983 to December 1986.

of amniotic fluid fibroblasts were done. When the etiology and the underlying disorder could not be determined, hydrops fetalis was diagnosed antenatally as IHF.

Intrauterine treatment comprised the following: Firstly, in order to maintain and increase serum protein concentration, albumin and/or packed red blood cells (PRC) were injected into the fetal abdominal cavity using ultrasound visualization. The amount of albumin injected was two to four grams added to the total amount of protein contained in the ascitic fluid removed from the fetus. The amount of PRC injected was determined according to BowmaN's method [3]. Serial paracenteses and thoracocenteses were performed to decompress the thoracic cavities.

To evaluate the therapeutic effects in utero, changes in the degree of edema, ascites and pleural effusion were determined, using real-time ultrasound at least once a week, and the hourly fetal urine production rate (HFUPR) was measured both immediately before and 24 hours after the intrauterine treatment was performed, using the method of CAMPBELL et al. [4]. In brief, HFUPR was calculated after the fetal bladder volume was observed every five minutes for a three hours period, using real-time ultrasound. When HFUPR increased to 150 percent or more within 24 hours after the intrauterine treatment, there was judged to be an "increase of HFUPR". Fetal cardiac function was evaluated by fetal echocardiography once a week.

Fetal well-being was monitored by using cardiotocography at least once a day. Fetal lung maturation was estimated by means of the lecithin/ sphingomyelin $(\mathrm{L} / \mathrm{S})$ ratio in the amniotic fluid.

When edema and fluid accumulation in serous cavities increased despite intrauterine treatment, and/or when fetal distress was evident on the cardiotocogram, the pregnancy was terminated in order to give immediate treatment to the neonate.

\section{Results}

At the time of initial diagnosis, the gestational age ranged from 26 to 32 weeks. All fetuses had edema (skin thickness over $5 \mathrm{~mm}$ [7]). Two had pleural effusion alone, three had only ascites, and two had both pleural effusion and ascites (table II).

Injection of albumin and/or PRC into the fetal abdominal cavity was performed twice in six cases and four times in one, at intervals of 10 to 14 days. Abdominal paracenteses were performed twice in two, three times in one and four times in two. Thoracocenteses were performed once in two cases and three times in one.

With respect to evaluation of the effects of therapy, the HFUPR was measured before and after the intrauterine treatment in five. In three of these five, the HFUPR increased. In no case did the HFUPR decrease. In two in whom the HFUPR did not increase, one had a negative balance of protein, and in the other, the serum protein concentration increased from $2.0 \mathrm{~g} / \mathrm{dl}$ immediately before the second injection to $2.9 \mathrm{~g} / \mathrm{dl}$ at delivery. This infant was delivered six days after the second injection. In two with no pleural effusion, the HFUPR increased, but it increased in only one of three with pleural effusion (table II).

In one (case 6), signs of hydrops fetalis disappeared completely in utero, and edema decreased significantly in case 7 . In the other five, signs of hydrops fetalis remained unchanged in utero.

The cardiotocogram revealed no ominous signs in six. In one (case 2), the cardiotocogram revealed late decelerations during labor. 
There were no stillbirths. Gestational age at birth ranged from 33 to 40 weeks. The interval between the initial diagnosis and the delivery ranged from 3 to 14 weeks. Apgar scores at one minute were 3 or less in three, 4 to 6 in two, and 7 or over in two. The umbilical artery $\mathrm{pH}$ was less than 7.15 in two, 7.15 to 7.19 in one and 7.20 or over in three. In one with an Apgar score of 9 at one minute, the umbilical artery $\mathrm{pH}$ was not measured (table III).

The laboratory data derived from the cord blood is shown in table IV. One had anemia; the values of serum protein were less than $3.0 \mathrm{~g} / \mathrm{dl}$ in two, 3.0 to $4.0 \mathrm{~g} / \mathrm{dl}$ in one, and $4.0 \mathrm{~g} / \mathrm{dl}$ or over in four.

Four with pleural effusion died of respiratory failure within 24 hours after delivery. The weight of the lungs was significantly low. Two of three without pleural effusion survived. One without pleural effusion died of sepsis on the fifth day (table IV). In all cases, the etiology and the underlying disorders were not detected in examinations done throughout the neonatal period and at autopsy.

Table II. Clinical data on seven fetuses with IHF treated in utero

\begin{tabular}{|c|c|c|c|c|c|c|c|c|}
\hline \multirow{3}{*}{$\begin{array}{l}\text { Case } \\
\text { no. }\end{array}$} & \multirow{3}{*}{$\begin{array}{l}\text { Time of } \\
\text { diagnosis } \\
\text { (weeks) }\end{array}$} & \multicolumn{4}{|c|}{ Ultrasonic manifestation } & \multirow{3}{*}{$\frac{\text { FUPR }^{1}}{\text { (Changes }}$} & $\mathrm{CTG}^{2}$ & $\mathrm{FS}^{3}$ \\
\hline & & \multicolumn{2}{|c|}{ Edema } & \multirow[t]{2}{*}{ Ascites } & \multirow{2}{*}{$\begin{array}{l}\text { Pleural } \\
\text { effusion }\end{array}$} & & ntrauter & atment) \\
\hline & & Head & Trunk & & & & & \\
\hline 1 & 29 & + & + & + & - & & $\mathrm{N}^{4}$ & $\mathrm{NC}^{5}$ \\
\hline 2 & 27 & + & + & + & + & & $\mathrm{N}$ & NC \\
\hline 3 & 28 & + & + & + & + & $\mathrm{NC}$ & $\mathbf{N}$ & $\mathrm{NC}$ \\
\hline 4 & 32 & + & + & \pm & \pm & Increase & $\mathbf{N}$ & NC \\
\hline 5 & 30 & + & + & $\bar{t}$ & $\overline{-}$ & Increase & $\mathbf{N}$ & $\mathrm{NC}$ \\
\hline 6 & 26 & - & + & + & - & Increase & $\mathbf{N}$ & NC \\
\hline 7 & 30 & + & + & - & + & $\mathrm{NC}$ & $\mathbf{N}$ & NC \\
\hline
\end{tabular}

${ }^{1}$ Fetal urine production rate, ${ }^{2}$ Cardiotocogram, ${ }^{3}$ Bilateral fractional shortening of ventricles, ${ }^{4}$ normal pattern, ${ }^{5}$ no change

Table III. Clinical data on seven neonates with IHF who received intrauterine treatment

\begin{tabular}{|c|c|c|c|c|c|c|c|c|}
\hline $\begin{array}{l}\text { Case } \\
\text { no. }\end{array}$ & $\begin{array}{l}\text { Time of } \\
\text { diagnosis } \\
\text { (weeks) }\end{array}$ & $\begin{array}{l}\text { Time of } \\
\text { delivery } \\
\text { (weeks) }\end{array}$ & $\begin{array}{l}\text { Mode of } \\
\text { delivery }\end{array}$ & $\begin{array}{l}\text { Birth } \\
\text { weight } \\
\text { (g) }\end{array}$ & $\begin{array}{l}\text { Apgar } \\
\text { score } \\
(1 \mathrm{~min})\end{array}$ & $\begin{array}{l}\mathrm{UA}^{1} \\
\mathrm{pH}\end{array}$ & Outcome & $\begin{array}{l}\text { Cause of } \\
\text { death }\end{array}$ \\
\hline 1 & 29 & 35 & $\mathrm{CS}^{2}$ & 3380 & 7 & 7.266 & Living & \\
\hline 2 & 27 & 34 & $\mathrm{~V}^{3}$ & 3170 & 2 & 6.852 & $\begin{array}{l}\text { Neonatal } \\
\text { death }(3 \mathrm{~h})\end{array}$ & $\begin{array}{l}\text { Respiratory } \\
\text { failure }\end{array}$ \\
\hline 3 & 28 & 34 & $\mathrm{CS}$ & 4250 & 4 & 7.162 & $\begin{array}{l}\text { Neonatal } \\
\text { death }(15 \mathrm{~h})\end{array}$ & $\begin{array}{l}\text { Respiratory } \\
\text { failure }\end{array}$ \\
\hline 4 & 32 & 36 & $\mathrm{CS}$ & 3650 & 6 & 7.143 & $\begin{array}{l}\text { Neonatal } \\
\text { death }(7 \mathrm{~h})\end{array}$ & $\begin{array}{l}\text { Respiratory } \\
\text { failure }\end{array}$ \\
\hline 5 & 30 & 33 & $\mathrm{CS}$ & 3790 & 3 & 7.219 & $\begin{array}{l}\text { Neonatal } \\
\text { death }(5 \mathrm{~d})\end{array}$ & Sepsis \\
\hline 6 & 26 & 40 & V & 3180 & 9 & & Living & \\
\hline 7 & 30 & 33 & $\mathrm{CS}$ & 3380 & 2 & 7.314 & $\begin{array}{l}\text { Neonatal } \\
\text { death }(20 \mathrm{~h})\end{array}$ & $\begin{array}{l}\text { Respiratory } \\
\text { failure }\end{array}$ \\
\hline
\end{tabular}

${ }^{1}$ Umbilical artery, ${ }^{2}$ Cesarean section, ${ }^{3}$ Vaginal 
Table IV. Laboratory data on cord blood in seven neonates with IHF

\begin{tabular}{lccccccc}
\hline & 1 & 2 & 3 & 4 & 5 & 6 & 7 \\
\hline Intake/Output balance & & & & & & & \\
$\quad$ Amount of transfused albumin $(\mathrm{g})$ & 10 & 5 & 10 & 12 & 20 & 12 & 14 \\
Amount of transfused RBC (ml) & 105 & 0 & 0 & 0 & 0 & 0 & 0 \\
Amount of removed protein $(\mathrm{g})$ & 19 & 2.8 & 22.4 & 1.6 & 16 & 8 & 2.7 \\
\hline Cord blood findings & & & & & & & \\
Total protein (g/dl) & 4.3 & 4.1 & 2.0 & 4.6 & 3.6 & 4.6 & 2.9 \\
Serum albumin (g/dl) & 3.1 & 2.6 & & 3.5 & & & 1.8 \\
Total bilirubin (mg/dl) & 1.9 & 2.1 & & 1.5 & 3.4 & 2.6 & 0.8 \\
Sodium (mEq/L) & 132 & 126 & & 135 & 135 & & 136 \\
Chloride (mEq/L) & 106 & 101 & & 103 & & & 115 \\
Hb (g/dl) & 6.5 & 13.0 & 17.3 & 14.9 & 15.2 & 17.4 & 14.2 \\
Htc (\%) & 18.6 & 44 & & 47.8 & 44.3 & 51.2 & 44.4 \\
RBC $\left(\times 10^{4}\right)$ & 157 & & & 406 & 417 & 497 & 380 \\
Platelet $\left(\times 10^{4}\right)$ & 30.9 & & & 31.4 & 26.5 & & 28.1 \\
\hline
\end{tabular}

\section{Discussion}

A standard protocol for the management of NIHF has not been established, though hydrops fetalis due to tachyarrhythmia has been successfully treated during the perinatal period [10].

It remains controversial whether intrauterine treatment is sufficiently effective to save the life of the infant with NIHF. ETCHES and LEMONS [6] suggested that early diagnosis and delivery early in the third trimester of pregnancy, plus aggressive neonatal treatment, may improve the survival rate of those with NIHF. WATSON and CAMPBELL [14] reported that early diagnosis and antenatal treatment did not improve the outcome in NIHF, except for those due to cardiac arrythmia. However, they treated NIHF due to disorders other than cardiac arrythmia with abdominal paracenteses and thoracocenteses alone. We [12] reported that two fetuses with NIHF due to disorders other than tachyarrythmia were effectively treated in utero.

It has been reported that decreased plasma colloid osmotic pressure due to hypoproteinemia may play an important role in the onset and/or the progression of NIHF $[2,11]$, though the etiology of NIHF is heterogenous. The objective of intrauterine treatment is to curtail the pathophysiologic process and to preserve the fetus in good or fair condition until the optimal time to treat the IHF, postnatally is reached. For this purpose, albumin and/or PRC were injected into the fetal abdomen to maintain the fetal plasma colloid osmotic pressure. In the present study, evidence for progression of the hydropic changes was not seen and indeed signs of hydrops fetalis disappeared in utero in one, and skin thickness decreased in another. In three of the five cases in whom the HFUPR was measured, it increased within 24 hours after albumin injections. This result suggests that renal blood flow increased after the albumin injection, because changes in the HFUPR may reflect a change of renal blood flow [9]. In addition, the concentration of serum protein increased from 2.0 to $2.9 \mathrm{~g} / \mathrm{dl}$, six days after albumin injection in one, in whom fetal blood sampling was done. The increase of serum protein following albumin injection into the fetal abdomen may lead to an increase in plasma volume due to a shift of extracellular fluid from the extravascular to the intravascular compartment. Thus, albumin injection into the fetal abdominal cavity fulfilled the intention of maintaining fetal plasma colloid osmotic pressure. However, evidence that in two of the three with pleural effusion the HFUPR did not increase suggests that pleural effusion may inhibit the return of circulating blood into the heart due to an elevated intrathoracic pressure.

There is a significant difference between the outcome of IHF with pleural effusion and IHF without pleural effusion. SHImoKawa et al. [13] and CASTILLO et al. [5] reported that severe pleural effusion correlated with poor perinatal outcome because of it's association with hypoplastic lungs. 
Four of the babies with pleural effusion died of respiratory failure during the neonatal period, regardless of the intrauterine treatment they received and aggressive respiratory care given after birth. In addition, their lungs were significantly light in weight. In the present study, the cause and effect between the pleural effusion and hypoplastic lungs could not be determined because pleural effusion re-accumulated within 24 hours after thoracocenteses. WEINER et al. [15] reported that NIHF was treated successfully in utero, using continuous drainage of pleural effusion. There- fore, it may be advantageous to place an indwelling catheter into the thoracic cavity in cases of NIHF who have pleural effusions.

In conclusion, albumin injection into the fetal abdominal cavity is an effective procedure in order to save the life of a fetus with IHF but without pleural effusion. Although, in a case of IHF with pleural effusion, the procedure is effective in maintaining the fetal plasma colloid osmotic pressure, other therapy will have to be developed in order to enhance growth of the lungs.

\section{Summary}

Seven fetuses with idiopathic hydrops fetalis (IHF) were treated in utero by injecting albumin into the fetal abdominal cavity and by removal of accumulated fluid from the serous cavities.

Signs of hydrops fetalis disappeared in utero in one, and skin edema significantly decreased in another. In the other five, signs of hydrops fetalis remained unchanged in utero. The hourly fetal urine production rate (HFUPR) increased after albumin injection in three of five. The interval between the initial diagnosis and deliv-

ery ranged from 3 to 14 weeks. Gestational age at the time of delivery ranged from 33 to 40 weeks.

There were no stillbirths. Two of three without pleural effusion survived, but four with pleural effusion died of respiratory failure during the neonatal period due to pulmonary hypoplasia.

These results indicate that albumin injection into the fetal abdomen in utero deserves further attention and that other therapeutic methods should be established to enhance the development of the lungs in cases of intrauterine treatment of IHF with pleural effusion.

Keywords: Fetotherapy, idiopathic hydrops fetalis, ultrasound.

\section{Zusammenfassung}

\section{Intrauterine Behandlung des idiopathischen Hydrops feta- lis}

Wir behandelten 7 Feten mit idiopathischem Hydrops fetalis (IHF) intrauterin durch Albumininjektionen in die fetale Bauchhöhle mit anschließender wiederholter Punktion der gebildeten Flüssigkeitsansammlungen aus den serösen Höhlen.

Bei einem Feten gingen die Symptome völlig zurück, bei einem zweiten nahm das Hautödem deutlich ab. In 5 Fällen trat in utero keine Veränderung ein. Die fetale stündliche Urinproduktion nahm in 3 Fällen nach Albumininjektion in das fetale Abdomen zu. Das Intervall zwischen Erstdiagnose und Entbindung lag zwischen 3 und 14 Wochen, das Gestationsalter bei Geburt zwischen 33 und 40 Wochen.

Totgeburten traten nicht auf. 2 von 3 Kindern ohne Pleuraerguß überlebten, 4 mit Pleuraerguß starben jedoch an einem respiratorischen Versagen infolge hypoplastischer Lungen in der Neonatalperiode.

Die Ergebnisse zeigen, daß Albumininjektionen in das fetale Abdomen weitere Beachtung finden sollten und $\mathrm{da} ß$ ein therapeutischer Zugang zur Entwicklung der Lungen bei IHF mit Pleuraerguß erarbeitet werden muß.

Schlüsselwörter: Fetale Therapie, idiopathischer Hydrops fetalis, Ultraschall.

\section{Résumé}

Traitement in utéro de l'hydrops fatalis idiopathique Sept fotus avec hydrops idiopathique (I. H. F.) ont été traités in utéro par injection d'albumine dans la cavité abdominale du fœetus et par évacuation du liquide accumulé dans l'abdomen.

Les signes de l'hydrops ont disparu in utéro chez l'un de ces foetus et l'œdème épidermique a diminué considé- rablement chez un autre. Pour les 5 autres fœtus, les signes d'hydrops n'ont pas varié in utéro. Le taux de production d'urine fotale par heure (HFUPR) a augmenté après l'injection d'albumine dans l'abdomen chez 3 de ces fœtus.

L'intervalle entre le diagnostic initial et l'accouchement était de 3 à 14 semaines. L'âge de gestation au moment 
de l'accouchement était compris entre 33 et 40 semaines. Il n'y a eu aucun cas mort-né. Deux des trois foetus sans liquide pleural ont survécu, mais quatre fœetus avec liquide pleural sont morts de gêne respiratoire dans la période néonatale en raison d'une hypoplasie pulmonaire.
Ces résultats manifestent que l'injection d'albumine dans l'abdomen fœtal in utéro est digne d'intérêt et que les autres moyens thérapeutiques doivent être mis en œuvre pour activer le développement des poumons dans les cas de traitement in utéro de l'hydrops fotalis idiopathique avec épanchement pleural.

Mots-clés: Fœtothérapie, hydrops fetalis idiopathique, ultrasons.

Acknowledgements: We thank M. OHARA (Kyushu University) for comments on the manuscript.

\section{References}

[1] ANDERSEN HM, JM Drew, NA Beischer, AA HutCHISON, DW FORTUNE: Nonimmune hydrops fetalis: changing contribution to perinatal mortality. Br J Obstet Gynaecol 90 (1983) 636

[2] Barnes SE, EM Bryan, DA Harris, JD Boum: Oedema in the newborn. Mol Aspects Med 1 (1977) 187

[3] Bowman JM: The management of Rh-isoimmunization. Obstet Gynecol 52 (1978) 1

[4] Campbell S, JW Wladdimiroff, CJ Dewhurst: The antenatal measurement of fetal urine production. J Obstet Gynaecol Br Commonw 80 (1973) 680

[5] Castillo RA, LD Denoe, HA Hadi, S Martin, D GEIST: Nonimmunologic hydrops fetalis: Clinical experience and factors related to a poor outcome. Am J Obstet Gynecol 155 (1986) 812

[6] ETChes PC, JA Lemons: NIHF reports of 22 cases including three siblings. Pediatrics 64 (1979) 326

[7] Fleischer AC, AP Killam, FH Boelum, AA HutCHISON, TB JONES, MI ShaFF, JM BARRETT, AH LiNDSOFF, AE JAMES JR: Hydrops fetalis: Sonographic evaluation and clinical implication. Radiology 141 (1981) 163

[8] Hutchison AA, JM Drew, VYH Yu, ML WiLliAMS, DW ForTUNe, NA BEISCHER: Nonimmunologic hydrops fetalis: A review of 61 cases. Obstet Gynecol 59 (1982) 347

[9] Kossoff G: New clinical application. In: KuRJARK A (ed): Progress in Medical Ultrasound. Excerpta Medica, Amsterdam 1980
[10] RAMZin MS, S NAPFLIN: Transient intrauterine supraventricular tachycardia associated with transient hydrops fetalis. Case report. Br J Obstet Gynaecol 89 (1982) 965

[11] Sakamoto G., H Nakano, T Koyanagi, S Kubota, $T$ SHIN: Pathogenesis of edema in cases with hydrops fetalis. Acta Neonate J 17 (1981) 671

[12] Shimokawa H, H NaKano: Intrauterine treatment of nonimmunologic hydrops fetalis, ICS 665. Excerpta, Amsterdam 1985

[13] Shimokawa H, K Hara, T Koyanagi, T HirakAWA, E Hori, H MAEDA, H NAKANO: Intrauterine treatment of nonimmunologie hydrops fetalis associated with pleural effusion. Acta Obstet Gynaecol Jpn 37 (1985) 66

[14] Watson J, S Campbell: Antenatal evaluation and management in nonimmunologic hydrops fetalis. Obstet Gynecol 67 (1986) 589

[15] Weiner C, M Varner, K Pringle, H Hein, R Williamson, WL SMITH: Antenatal diagnosis and palliative treatment of nonimmune hydrops fetalis secondary extralabor sequestration. Obstet Gynecol 68 (1986) 275

Received September 9, 1987. Accepted October 9, 1987.

Hiroshi Shimokawa, M. D.

Department of Gynecology and Obstetrics

Faculty of Medicine

Kyushu University 60

Maidashi 3-1-1, Higashi-ku

Fukuoka 812, Japan 